\title{
Interferon- $\gamma$ Inhibits Scavenger Receptor Expression and Foam Cell Formation in Human Monocyte-derived Macrophages
}

\author{
Yong-jian Geng and Göran K. Hansson \\ Department of Clinical Chemistry, Gothenburg University Sahlgren's Hospital, S-413 45 Gothenburg, Sweden
}

\begin{abstract}
The scavenger receptor (ScR) mediates uptake of chemically modified low density lipoprotein (LDL) by human monocytederived macrophages. It is not down-regulated by high intracellular cholesterol levels, and exposure of macrophages to acetylated or oxidized LDL therefore leads to foam cell development. The hypothesis that this represents an important mechanism for intracellular cholesterol accumulation in atherosclerosis is supported by the finding of ScR expression in foam cells of atherosclerotic plaques. $T$ lymphocytes are also present in such plaques and it is known that $T$ cell products regulate macrophage activation. We have therefore studied the effect of interferon- $\gamma$ (IFN $\gamma$ ), a lymphokine secreted by activated $T$ lymphocytes, on the expression of ScR in human monocytederived macrophages. Binding and uptake of acetylated LDL were significantly reduced in macrophages exposed to recombinant IFN $\gamma$ or IFN $\gamma$-containing lymphocyte-conditioned media. Competition experiments showed that the IFN $\gamma$-regulated binding and uptake of acetylated LDL was mediated via ScR. IFN $\gamma$ exerted its effect on the saturable binding of acetylated LDL by reducing the number of cell surface binding sites without significantly affecting the affinity between acetylated LDL and its receptor. Northern analysis revealed that the type I ScR mRNA was significantly reduced in IFN $\gamma$-treated cells. Finally, IFN $\gamma$ treatment reduced intracellular cholesteryl ester accumulation and inhibited the development of foam cells in the cultures. In conclusion, our data show that IFNr blocks the development of macrophage-derived foam cells by inhibiting expression of ScR. This suggests that macrophage-T lymphocyte interactions may reduce intracellular cholesterol accumulation in the atherosclerotic plaque. (J. Clin. Invest. 1992. 89:1322-1330.) Key words: atherosclerosis • cholesterol • low density lipoprotein $\bullet$ lipoprotein receptors $\bullet$ lymphokines
\end{abstract}

\section{Introduction}

The appearance of lipid-laden foam cells is one of the hallmarks of the atherosclerotic plaque. Most of these cells express phenotypic markers of macrophages and are probably derived from circulating monocytes (1-4). The transformation of the monocyte-derived macrophage into a lipid-laden foam cell is still not completely understood, but it is likely that receptor-

Address reprint requests to Dr. Hansson, Department of Clinical Chemistry, Gothenburg University, Sahlgren's Hospital, S-413 45 Gothenburg, Sweden.

Received for publication 20 June 1991 and in revised form 18 November 1991.

J. Clin. Invest.

(C) The American Society for Clinical Investigation, Inc.

0021-9738/92/04/1322/09 \$2.00

Volume 89, April 1992, 1322-1330 mediated uptake of cholesterol-rich particles is of critical importance for the transformation process $(4,5)$.

Studies of lipid metabolism in cultured macrophages have led to the identification of a special type of lipoprotein receptor, the scavenger receptor (ScR), ${ }^{1}$ on these cells (5). ScR mediates uptake of lipoproteins and other proteins with an increased negative charge by receptor-expressing macrophages and endothelial cells (6). Among these modified lipoproteins are acetylated low density lipoprotein (AcLDL) and oxidized forms of LDL (7). In contrast to the receptor for native LDL (LDL-R), ScR is not down-regulated by increases in the intracellular cholesterol level (8). Therefore, the macrophage will continue to take up and process modified lipoproteins via ScR as long as it is present in the extracellular milieu. This results in an intracellular cholesterol accumulation and the transformation of the macrophage into a foam cell.

ScR cDNAs have recently been cloned both from bovine $(9,10)$, human (11), and murine sources (12). Two different types of ScR were identified, both of which are glycoproteins that appear to bind their ligands via a collagen-like domain in the extracellular carboxy-terminal portion of the molecule. Both the larger type I and the smaller type II ScR mRNA species were found in macrophage cell lines and macrophage-rich tissues including atherosclerotic plaques (9-13).

The regulation of ScR expression is largely unclear, but it has been observed that it increases when monocytes differentiate into macrophages (14) and when promonocytic cell lines such as THP-1 are stimulated by phorbol esters $(15,16)$. This suggests that $\mathrm{ScR}$ expression is linked to the differentiation and/or activation of the cell.

Macrophage activation is a two-step process in which the cell is first "primed" by the lymphokine, interferon- $\gamma$ (IFN $\gamma$ ), which is released by activated $T$ lymphocytes. The primed macrophage is capable of responding to activating stimuli such as bacterial endotoxins, resulting in an increased phagocytosis, free radical production, and the activation of the hexose monophosphate shunt (17).

The relation between macrophage differentiation and ScR expression and the role of IFN $\gamma$ in the former made it reasonable to believe that IFN $\gamma$ might affect ScR expression. We have therefore analyzed the effect of IFN $\gamma$ on $\mathrm{ScR}$ expression in human monocyte-derived macrophages. IFN $\gamma$ treatment resulted in down-regulation of $\mathrm{ScR}$ on the mRNA level and was followed by reduced AcLDL binding and internalization. This resulted in a decreased cholesteryl ester accumulation and an inhibition of the transformation of these macrophages into foam cells.

1. Abbreviations used in this paper: AcLDL, acetylated LDL, DiI, 1,1'dioctadecyl-1-3,3,3',3'-tetramethylindocarbocyanine perchlorate; HS, human serum; LCM, lymphocyte-conditioned medium; LDL-R, receptor for native LDL; LPDS, lipoprotein-deficient serum; ScR, scavenger receptor(s), receptor for modified LDL. 


\section{Methods}

Macrophage cultures. Buffy coats from the blood of healthy donors were obtained through the Blood Center of Sahlgren's Hospital. Mononuclear cells were isolated by Ficoll-paque centrifugation (Pharmacia, Uppsala, Sweden) and suspended in RPMI-1640 (Gibco, Paisley, UK) supplemented with $10 \%$ fetal bovine serum (FCS), $10 \%$ pooled human serum (HS), $50,000 \mathrm{U} / \mathrm{ml}$ penicillin $\mathrm{G}$, and $50 \mu \mathrm{g}$ of streptomycin. Monocytes were enriched by adherence during a 1-h incubation at $37^{\circ} \mathrm{C}$ in a $175-\mathrm{cm}^{2}$ polystyrene cell culture flask (Nunc, Roskilde, Denmark). Nonadherent cells were removed by washing the flask three times in PBS ( $150 \mathrm{mM} \mathrm{NaCl}, 10 \mathrm{mM}$ phosphate buffer, $\mathrm{pH}$ 7.2). Adherent cells were harvested with a rubber policeman and replated in new culture dishes at $2 \times 10^{5} \mathrm{cells} / \mathrm{ml}$. The medium was changed after 3-4 $\mathrm{d}$ and IFN $\gamma$ and other stimuli were added at this time point. Cell viability determined by trypan blue exclusion was $>95 \%$ in all experiments. The purity of the monocyte-macrophage cultures was evaluated by immunofluorescent staining with the Leu-M3 antibody, (Becton, Dickinson \& Co., Mountain View, CA), which recognizes the CD14 cluster of differentiation that is specific for monocytes and macrophages (18). More than $90 \%$ of the cells were Leu-M3 positive 3-4 d after plating and morphologic examination of Giemsa-stained preparations supported the conclusion that they were monocyte-derived macrophages.

Smooth muscle cell cultures. Rat aortic smooth muscle cells were isolated and grown as described (19). Cells of the third and fourth passages were used for experiments.

Lymphocyte-conditioned medium (LCM) and recombinant IFN Nonadherent mononuclear cells were obtained as described above and resuspended in culture medium with 5\% FCS. Morphologic and immunophenotypic (CD3 marker, Leu-4; CD19 marker, Leu-12; both from Becton Dickinson \& Co.) examination revealed that these cells were almost exclusively lymphocytes, with a dominance of $\mathrm{CD}^{+} \mathrm{T}$ lymphocytes. The cultures were stimulated for $2 \mathrm{~d}$ with phytohemagglutinin (Burroughs Wellcome, London, UK) at $2 \mu \mathrm{g} / \mathrm{ml}$ to activate the T lymphocytes (20). At the end of stimulation, LCM was harvested by centrifugation, filtered through a $0.22-\mu \mathrm{m}$ filter (Millipore Corp., Bedford, MA), and stored at $-20^{\circ} \mathrm{C}$. Recombinant human IFN $\gamma$ with a specific activity of $1.8 \times 10^{7} \mathrm{U} / \mathrm{mg}$ was kindly provided by Genentech, South San Francisco, CA.

Lipoprotein binding and uptake. Macrophage binding and uptake of AcLDL and native LDL was analyzed by flow cytometry using lipoproteins labeled with the fluorescent probe, $1,1^{\prime}$-dioctadecyl-1-3,3,3',3'tetramethylindocarbocyanine perchlorate (DiI). DiI-labeled AcLDL and native LDL have been successfully utilized to visualize the uptake of lipoproteins by macrophages and endothelial cells (21, 22). DiI-labeled and unlabeled AcLDL and native LDL were obtained from Biogenesis, Bournemouth, UK. Macrophages were washed with PBS and incubated with Dil-AcLDL or Dil-LDL dissolved in RPMI 1640 medium containing $10 \%$ lipoprotein-deficient human serum (LPDS) or $5 \%$ FCS. The concentration of Dil-labeled lipoprotein was $5 \mu \mathrm{g} / \mathrm{ml}$ when not otherwise stated in the text. Cells were incubated at $4^{\circ} \mathrm{C}$ for $30 \mathrm{~min}$ for the binding assay and at $37^{\circ} \mathrm{C}$ for $3 \mathrm{~h}$ for uptake studies. Various concentrations of unlabeled AcLDL or native LDL were added together with the fluorescent lipoprotein in competition experiments. At the end of incubation, the cells were gently removed from the dish with a rubber policeman, dispensed in PBS, and fixed in $1 \%$ paraformaldehyde in PBS.

Flow cytometry. Fixed cells were washed twice in PBS and analyzed in a FACScan flow cytometer (Becton Dickinson \& Co.) equipped with an argon laser that excited the fluorescent probe at $488 \mathrm{~nm}$. Emitted fluorescence was collected at $550-595 \mathrm{~nm}$ (the FL2 photomultiplier of the FACScan). Data were analyzed using the Lysys software program and a light scatter gate was established to exclude cell debris. Autofluorescent signals from unlabeled cells were used as negative controls in each experiment. Specific fluorescent intensity was calculated by subtracting autofluorescent intensity from the mean fluorescent intensity of Dil-labeled cells. For quantitation of AcLDL binding, the instrument was calibrated using a series of R-phycoerythrin-labeled micro- beads (Flow Cytometry Standards Corp., Research Triangle Park, NC), which permitted an estimate of the number of fluorochromes bound at a given specific fluorescent intensity in the FL2 photomultiplier (23).

Fluorescent microscopy and cytochemistry. Cells were cultured for $2 \mathrm{~d}$ in eight-well chamber slides (Miles Scientific, Naperville, IL) in medium containing $10 \% \mathrm{FCS}, 10 \% \mathrm{HS}$, and $25 \mu \mathrm{g} / \mathrm{ml}$ AcLDL. For fluorescent microscopic analysis, they were incubated with DiI-AcLDL at $5 \mu \mathrm{g} / \mathrm{ml}$ at $37^{\circ} \mathrm{C}$ for $4 \mathrm{~h}$ (uptake studies) or at $4^{\circ} \mathrm{C}$ for $30 \mathrm{~min}$ (binding studies), rinsed three times in PBS, fixed in $1 \%$ formaldehyde in PBS, and mounted in PBS/glycerol. DiI fluorescence was analyzed in a fluorescent microscope (Microphot, Nikon, Tokyo, Japan) using a rhodamine filter set. For cytochemical analysis of cellular lipids, the cultures were washed with PBS, fixed for $1 \mathrm{~h}$ with $4 \%$ formaldehyde in PBS, and then briefly immersed in $60 \%$ isopropanol. Cells were stained with $3 \%$ Oil Red $\mathrm{O}$ in $60 \%$ isopropanol for $1 \mathrm{~h}$ at $4^{\circ} \mathrm{C}$, rinsed in PBS, and mounted for light microscopic examination. Previously established criteria were used for identifying and counting foam cells $(1,24)$. In essence, foam cells were defined as macrophages in which the entire cytoplasm was filled with Oil Red O-stainable lipid droplets.

Cholesterol analysis. Cells were cultured in $10-\mathrm{cm}^{2}$ dishes with medium containing $10 \%$ FCS and $10 \%$ HS. They were first incubated for 3 d with IFN $\gamma$, then rinsed with PBS, and incubated for $20 \mathrm{~h}$ with AcLDL at $50 \mu \mathrm{g} / \mathrm{ml}$ or native LDL at $100 \mu \mathrm{g} / \mathrm{ml}$ in medium containing $2.5 \%$ FCS. At the end of incubation, the cells were rinsed three times in ice-cold PBS. Lipid extraction was performed in the culture dishes by adding $1 \mathrm{ml}$ of $n$-hexane/isopropanol (3:2, vol/vol) and incubating at room temperature for $30 \mathrm{~min}$ (25). This was repeated three times and the supernatants were pooled for lipid extraction. The remaining nonlipid material in the culture dish was dissolved in $0.2 \mathrm{M} \mathrm{NaOH}$ and the protein concentration was determined by the method of Lowry et al. (26) using bovine serum albumin as a standard. The organic solvent was evaporated under nitrogen and the lipid extract was dissolved in chloroform. The lipids were separated and analyzed using an Iatroscan TH-10 (Newman-Howells, Winchester, UK) thin-layer chromatography system with flame ionization detection (27). In brief, aliquots were applied to Chromarod SIII quartz rods (Newman-Howells) coated with silica gel and lipids separated with $n$-hexane/diethyl ether $(4: 1, \mathrm{vol} / \mathrm{vol})$ as the mobile phase. Quantitation was performed with pure preparations of cholesteryl ester, free cholesterol, and triglycerides as standards.

$R N A$ isolation. Total RNA was isolated from human monocytederived macrophages and rat smooth muscle cells using the $\mathrm{LiCl} / \mathrm{urea}$ method (28). In brief, cells were washed in PBS and then lysed in $3 \mathrm{M}$ lithium chloride, $6 \mathrm{M}$ urea, $0.1 \%$ sodium lauryl sulphate, $50 \mathrm{mM}$ Tris$\mathrm{HCl}, \mathrm{pH} 7.5,10 \mathrm{mM}$ 2-mercaptoethanol, $5 \mathrm{mM}$ EDTA. The lysate was sedimented at $4^{\circ} \mathrm{C}$ overnight and centrifuged at $20,000 \mathrm{~g}$ for $20 \mathrm{~min}$. DNA was removed by digestion for $30 \mathrm{~min}$ at $37^{\circ} \mathrm{C}$ with RNase-free DNase I (Boehringer Mannheim, Mannheim, FRG) in the presence of RNasin (Boehringer Mannheim). RNA was further purified by phenolchloroform extraction and precipitated with ethanol and $5 \mathrm{M} \mathrm{NaCl}$. Aliquots dissolved in $10 \mathrm{mM}$ Tris- $\mathrm{HCl}, \mathrm{pH} 7.4 ; 5$ mM EDTA were used for RNA quantitation by spectrophotometry at $260 \mathrm{~nm}$.

Oligonucleotide probes. Antisense oligonucleotides were constructed on the basis of the published cDNA sequence for the bovine ScR (9). 30-mers were synthesized with a protective trityl group on a DNA synthesizer (model 391, Applied Biosystems, Inc., Foster City, CA). The protective group was removed by reversed phase chromatography on an OPC purification cartridge (Applied Biosystems, Inc.) and the oligonucleotides labeled with [ $\left.{ }^{32} \mathrm{P}\right] \mathrm{ATP}$ at the 5 ' end using T4 polynucleotide kinase (Boehringer Mannheim). Several 30-mers were initially tested by Northern hybridization and one of them was found to hybridize to an mRNA species of the appropriate size in macrophages but not in rat smooth muscle cells. It was used for further experiments. The sequence of this oligonucleotide was 5'-GAGATTGGCTTCATTATCTGAAAGATACTG-3', corresponding to bases no. 372-402 of the $\alpha$-helical coiled coil-encoding segment.

Northern hybridization. $15 \mu \mathrm{g}$ of total RNA was denatured in $50 \%$ formamide and separated by agarose electrophoresis in the presence of $0.7 \%$ formaldehyde, at $50 \mathrm{~V}$ overnight. RNA was transferred to Hy- 
bond-C extra membranes (Amersham, Amersham, UK) by capillary blotting. After baking at $80^{\circ} \mathrm{C}$, the membranes were prehybridized in $5 \times$ Denhardt's solution, $6 \times$ SSC, $0.1 \%$ SDS for $4 \mathrm{~h}$ at $40^{\circ} \mathrm{C}$ and then hybridized at $40^{\circ} \mathrm{C}$ overnight with the oligonucleotide probes dissolved at $2 \times 10^{6} \mathrm{cpm} / \mathrm{ml}$ in fresh prehybridization buffer. Membranes were washed in $2 \times \mathrm{SSC}, 0.1 \% \mathrm{SDS}$ at $55^{\circ} \mathrm{C}$ using a Hybaid washing apparatus (Hybaid, Teddington, UK) and exposed to Kodak X-Omat AS film at $-70^{\circ} \mathrm{C}$.

Statistical analysis. Differences between means were evaluated by using Student's $t$ test.

\section{Results}

Flow cytometric characterization of macrophage AcLDL uptake. Human peripheral blood monocytes differentiated into macrophages during 1 wk of culture. This was accompanied by an increased capacity to internalize AcLDL labeled with the fluorescent probe, DiI. DiI-AcLDL uptake during a 3-h incubation at $37^{\circ} \mathrm{C}$ could be analyzed both by fluorescence microscopy and flow cytometry. By using the latter technique, we determined the uptake of Dil-AcLDL by macrophages in a mixed cell population together with lymphocytes (Fig. 1). The two cell types could be separated by their light scatter characteristics, and the DiI-AcLDL uptake was evaluated in separate fluorescent intensity histograms for each cell type. Macrophages but not lymphocytes exhibited DiI fluorescence signif- cantly above background autofluorescence after incubation with Dil-AcLDL. This indicates that the former cell type was capable of internalizing AcLDL. We also evaluated DiIAcLDL uptake by rat aortic smooth muscle cells and found that these cells have a low capacity for DiI-AcLDL uptake (data not shown).

The specificity of the uptake mechanism was characterized by incubating macrophages with Dil-AcLDL in the presence of excess amounts of either unlabeled AcLDL or unlabeled native LDL. Fig. 2 shows that unlabeled AcLDL but not native LDL could block the uptake of DiI-AcLDL. This indicates a specific uptake of the acetylated lipoprotein and strongly suggests that ScR constitutes the major route for uptake of AcLDL by these cells.

Effect of recombinant and natural IFN $\gamma$ on AcLDL uptake. We used the flow cytometric assay to determine whether IFN $\gamma$ can modulate AcLDL uptake by human monocyte-derived macrophages. Incubation of these cells with $100 \mathrm{U} / \mathrm{ml}$ recombinant human IFN $\gamma(\mathrm{rIFN} \gamma)$ for $3 \mathrm{~d}$ resulted in a $50 \%$ inhibition of DiI-AcLDL uptake (Table I). This effect was abolished in the presence of a polyclonal anti-IFN $\gamma$ antibody, indicating that it was specific for the lymphokine and not due to any contaminant of the recombinant preparation (Table I). rIFN $\gamma$ treatment had no significant effect on the autofluorescent properties of the cells (data not shown).

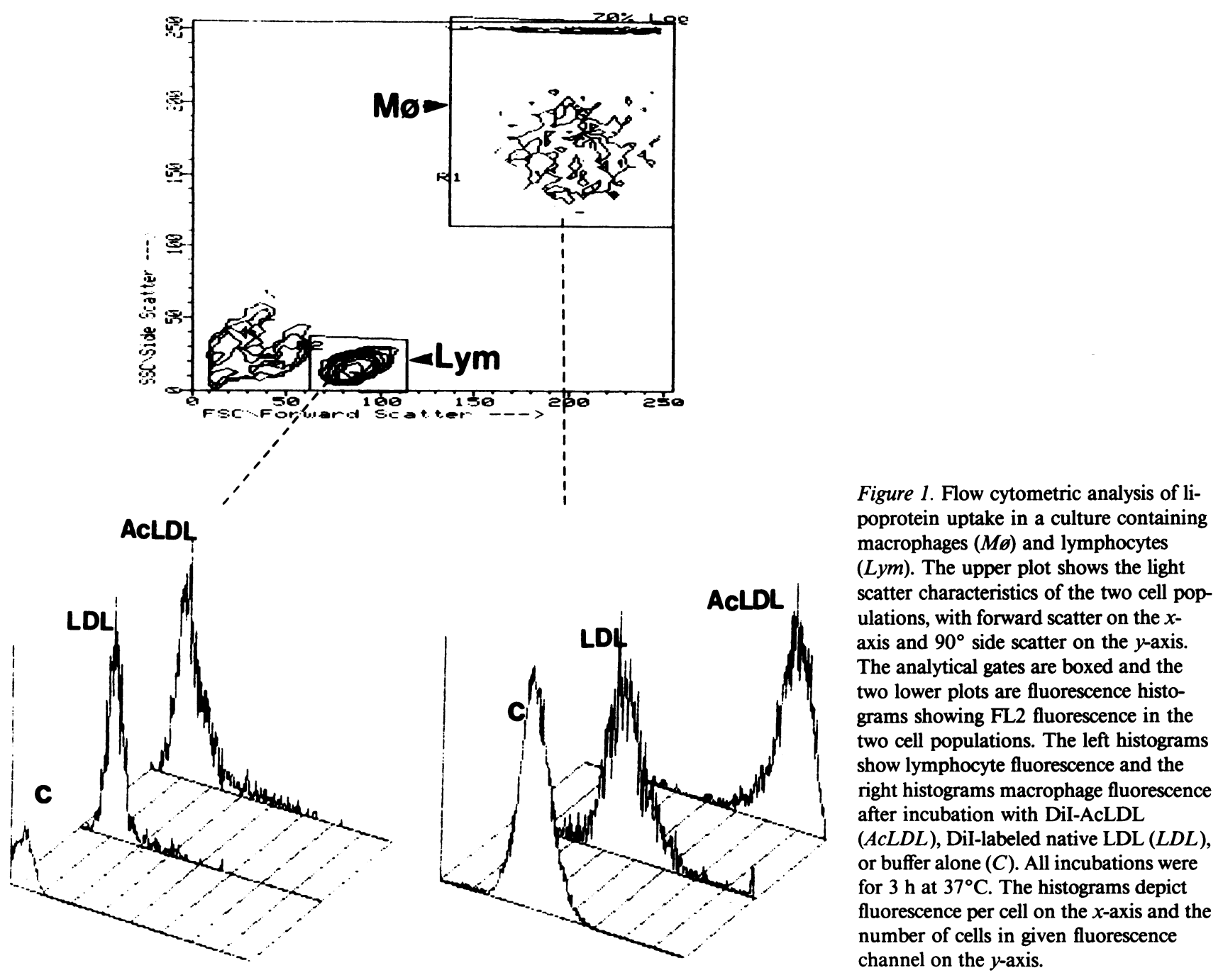




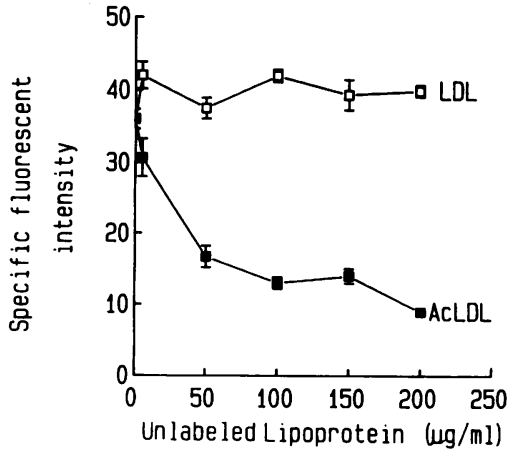

Figure 2. Specificity of DiI-AcLDL uptake in monocyte-derived macrophages as evaluated by competition with excess amounts of unlabelled native LDL $(L D L)$ or acetylated $(A c L D L)$. Cells were incubated for $3 \mathrm{~h}$ at $37^{\circ} \mathrm{C}$ with Dil-AcLDL at 5 $\mu \mathrm{g} / \mathrm{ml}$ in culture medium in the presence of the indicated concentra-

tions of unlabeled LDL or AcLDL. DiI fluorescence was analyzed by flow cytometry and specific fluorescent intensity determined by subtracting mean fluorescent intensity of unlabeled cells (autofluorescence) from that of Dil-AcLDL incubated cells. Bars represent means $\pm \operatorname{SEM}(n=4)$.

The capacity of natural IFN $\gamma$ to modulate AcLDL uptake was studied with the use of conditioned media (LCM) from lymphocyte cultures in which the $T$ lymphocyte population was activated by addition of the lectin, phytohemagglutinin. When such LCM preparations were added to macrophages cultures, DiI-AcLDL uptake was reduced by $32 \%$ (Table I). This was due to the presence of IFN $\gamma$ in the LCM, since addition of anti-IFN $\gamma$ to LCM abolished the inhibitory effect (Table I). Anti-IFN $\gamma$ antibodies or PHA alone had no effect on AcLDL uptake (Table I).

Bacterial lipopolysaccharides, which activate primed macrophages, may down-regulate AcLDL uptake (29). The possibility that a lipopolysaccharide/endotoxin contamination was responsible for the effect ascribed to IFN $\gamma$ was addressed in a separate series of experiments. Addition of polymyxin B, which binds to lipopolysaccharide and inhibits its biologic activities, slightly changed but did not abolish the effect of rIFN $\gamma$ on AcLDL uptake (Table I). This together with the finding that anti-IFN $\gamma$ antibodies abolished the effect of both rIFN $\gamma$ and LCM, show that endotoxin contamination was not responsible for the effects of the different IFN $\gamma$ preparations.

Table I. Effects of LCM and rIFN $\gamma$ on DiI-AcLDL Uptake by Human Monocyte-derived Macrophages

\begin{tabular}{lccc}
\hline & \multicolumn{3}{c}{ Treatment $^{\ddagger}$} \\
\cline { 2 - 4 } Additives* & Control & LCM & rIFN $\gamma$ \\
\hline None & 100 & $69.3 \pm 2.2^{\S}$ & $48.7 \pm 1.3^{\S}$ \\
Anti-IFN $\gamma$ & $95.3 \pm 4.5$ & $92.2 \pm 3.7$ & $90.9 \pm 2.0$ \\
Polymyxin B & $109.4 \pm 6.9$ & $64.9 \pm 2.3^{\S}$ & $62.0 \pm 5.4^{\S}$ \\
\hline
\end{tabular}

* Polyclonal blocking antibody $(50 \mu \mathrm{g} / \mathrm{ml})$ against human IFN $\gamma$ (anti-IFN $\gamma$, Boehringer Mannheim) and polymyxin B ( $50 \mu \mathrm{g} / \mathrm{ml}$, Sigma Chemical Co., St. Louis, MO) were added together with LCM or rIFN $\gamma$. Data show Dil-AcLDL uptake (specific fluorescent intensity) in percent of fluorescence in untreated control cultures. Mean \pm SEM, $n=4$.

₹ The cells were treated with LCM $(100 \mu \mathrm{l} / \mathrm{ml})$ and $\operatorname{rIFN} \gamma(1,000$ $\mathrm{U} / \mathrm{ml}$ ) for $3 \mathrm{~d}$ and then incubated with $5 \mu \mathrm{g} / \mathrm{ml} \mathrm{Dil-AcLDL}$ at $37^{\circ} \mathrm{C}$ for $3 \mathrm{~h}$.

$\S$ Significantly different from untreated control cultures $(P<0.05)$.
Dose dependency of inhibitory effect of IFN $\gamma$ on AcLDL uptake. To characterize the effect of rIFN $\gamma$ on Dil-AcLDL uptake in macrophages, we examined DiI-AcLDL uptake by monocyte-derived macrophages from 17 different healthy donors. The inhibitory effect of rIFN $\gamma$ on Dil-AcLDL uptake showed a distinctive dose-response relationship (Fig. 3). As little as $10 \mathrm{U} / \mathrm{ml}$ of rIFN $\gamma$ was able to reduce the uptake by $30 \%$ and increasing concentrations of rIFN $\gamma$ led to further inhibition of Dil-AcLDL uptake (Fig. 3).

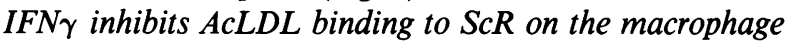
cell surface. To test whether the inhibitory effect of IFN $\gamma$ on the uptake of AcLDL was due to a reduction in AcLDL binding to the cell surface, macrophages were incubated with DiIAcLDL for $30 \mathrm{~min}$ on ice, washed with ice-cold buffer, immediately fixed, and analyzed by flow cytometry. Fig. 4 shows that this technique permitted the detection of AcLDL binding to the cells. The fluorescent signal was significantly reduced in rIFN $\gamma$-treated cells (Fig. 4), indicating that IFN $\gamma$ reduces the binding of AcLDL to the cell surface.

AcLDL binding to macrophages was further characterized by using different concentrations of fluorescent ligand and addition of excess concentrations of unlabeled AcLDL (Fig. $5 a$ ). DiI-AcLDL binding was saturable and inhibited by adding excess amounts of unlabeled AcLDL, indicating that it represented binding to a limited number of high-affinity receptors. Treatment of the cells with rIFN $\gamma$ reduced saturable binding of DiI-AcLDL without significantly affecting the nonspecific binding that occurred in the presence of excess amounts of unlabeled AcLDL (Fig. 5 a).

The effect of IFN $\gamma$ on AcLDL binding was further analyzed after calibration of the flow cytometer to permit direct quantitation of the number of fluorescent particles bound to each cell (23). The binding of AcLDL to monocyte-derived macrophages could then be characterized by Scatchard analysis (Fig. $5 \mathrm{~b}$ ). With this approach, the number of high-affinity binding sites for AcLDL $\left(B_{\max }\right)$ was estimated to $5.1 \times 10^{4}$ per untreated macrophage with a $K_{\mathrm{d}}=3.8 \times 10^{-9} \mathrm{M}$. Treatment of the cells with IFN $\gamma$ significantly reduced the number of binding sites $\left(B_{\max }=3.8 \times 10^{4}\right.$ per cell, $\left.P<0.01\right)$ without any considerable change in the affinity of the receptor $\left(K_{\mathrm{d}}=4.0\right.$ $\times 10^{-9} \mathrm{M}$ ) (Fig. 5 b) .

Localization of AcLDL in the cytoplasm. Fluorescent microscopy was used to analyze the cellular distribution of Dil-

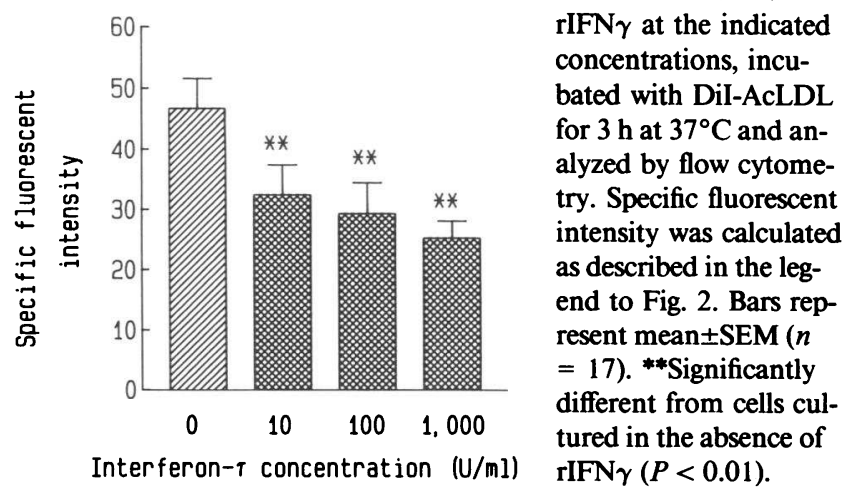

Figure 3. rIFN $\gamma$ inhibits DiI-AcLDL uptake by macrophages. Cells were treated for $3 \mathrm{~d}$ with rIFN $\gamma$ at the indicated concentrations, incufor $3 \mathrm{~h}$ at $37^{\circ} \mathrm{C}$ and analyzed by flow cytomeend to Fig. 2. Bars represent mean $\pm \operatorname{SEM}(n$ $=17) .{ }^{* *}$ Significantly different from cells cul$\operatorname{rIFN} \gamma(P<0.01)$. 


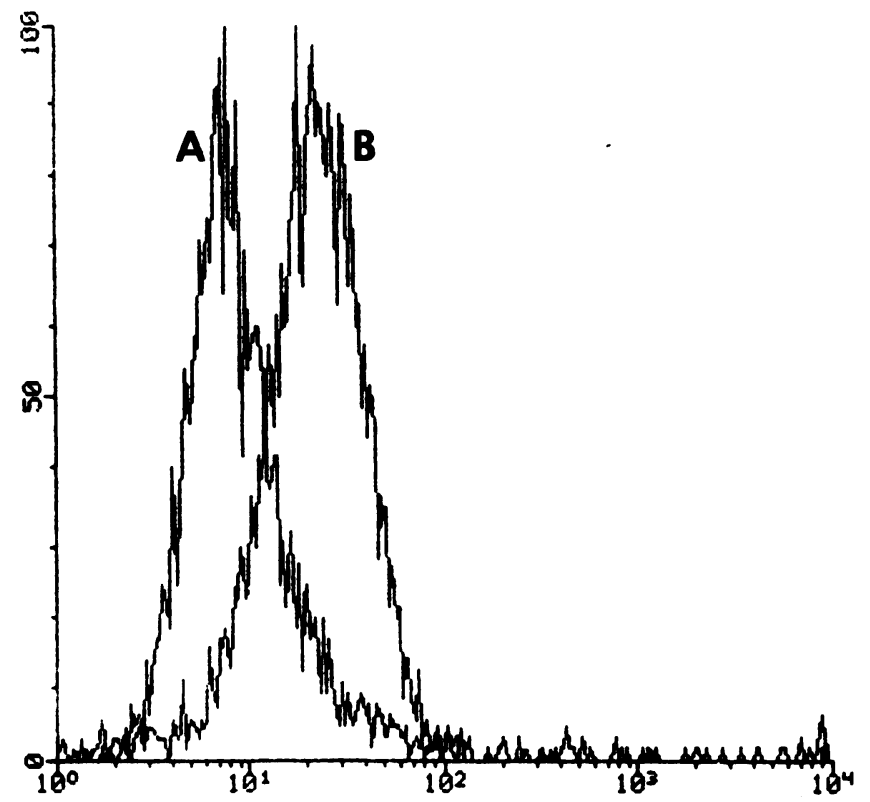

Figure 4. rIFN $\gamma$ inhibits Dil-AcLDL binding to macrophages. Cells were cultured for three days in the presence $(A)$ or absence $(B)$ of rIFN $\gamma$ at $100 \mathrm{U} / \mathrm{ml}$, incubated with Dil-AcLDL at $5 \mu \mathrm{g} / \mathrm{ml}$ for $30 \mathrm{~min}$ at $4^{\circ} \mathrm{C}$, and analyzed by flow cytometry. The histogram shows fluorescent intensity per cell on the $x$-axis and the number of positive cells (relative units) on the $y$-axis.

AcLDL in macrophages. After internalization, Dil-AcLDL is rapidly degraded in the lysosomes and the DiI molecule accumulates in the lysosomal membrane $(21,22)$. This was confirmed by the present observation of a spotted, perinuclear DiI fluorescence in macrophages incubated with Dil-AcLDL at 5 $\mu \mathrm{g} / \mathrm{ml}$ for $3 \mathrm{~h}$ at $37^{\circ} \mathrm{C}$ (Fig. $6, a$ and $c$ ). The fluorescent intensity was clearly reduced in rIFN $\gamma$-treated cells, but the distribution of the fluorescent material was similar to that in untreated cells (Fig. 6, $b$ and $d$ ).

IFN $\gamma$ inhibits $S c R$ expression on the $m R N A$ level. To evaluate the molecular basis for the effect of IFN $\gamma$ on AcLDL uptake in human monocyte-derived macrophages, we analyzed ScR mRNA levels in these cells by Northern hybridization. Total
RNA was isolated from $\operatorname{rIFN} \gamma$ treated $(1,000 \mathrm{U} / \mathrm{ml}$ for $3 \mathrm{~d})$ and untreated macrophages and also from rat aortic smooth muscle cells, which do not show significant ScR activity. After blotting to nitrocellulose membranes, RNA was hybridized to ${ }^{32} \mathrm{P}$-labeled oligonucleotide probes constructed from the published cDNA sequence for the bovine type I ScR (9). A prominent band at $4.4 \mathrm{~kb}$ corresponding to the ScR type I mRNA was present in macrophages but not in smooth muscle cells (Fig. 7). This band was drastically reduced in macrophages treated with rIFN $\gamma$ (Fig. 7), indicating that rIFN $\gamma$ inhibits type I ScR expression on the mRNA level. No hybridization to the ScR type II mRNA at $3.2 \mathrm{~kb}$ could be detected in these experiments.

IFNy inhibits ScR-mediated cholesteryl ester accumulation. Uptake of modified LDL via ScR leads to intracellular cholesterol accumulation because ScR cannot be downregulated by increasing intracellular cholesterol concentrations (58). The accumulating cholesterol is largely present as cholesteryl ester droplets, whereas free cholesterol, mainly in cellular membranes, is less affected (5-8).

We tested whether rIFN $\gamma$ treatment could modulate cholesterol accumulation in monocyte-derived macrophages exposed to AcLDL. These cells contained $\sim 60 \mu \mathrm{g}$ of cholesterol per milligram of cell protein when cultured under standard conditions (RPMI-1640 medium with 10\% FCS and 10\% HS). Fig. 8 shows that the total cellular cholesterol concentration reaches $130 \mu \mathrm{g} / \mathrm{mg}$ cell protein in macrophages exposed to $50 \mu \mathrm{g} / \mathrm{ml}$ AcLDL for $20 \mathrm{~h}$. In contrast, incubation with native LDL at $100 \mu \mathrm{g} / \mathrm{ml}$ did not change the cellular cholesterol concentration significantly (data not shown). Preincubation with rIFN $\gamma$ at $1,000 \mathrm{U} / \mathrm{ml}$ for $3 \mathrm{~d}$ reduced cholesterol accumulation by $50 \%$ (Fig. 8). This was exclusively due to a reduction in cholesteryl ester concentration, whereas free cholesterol was not affected by rIFN $\gamma$ (Fig. 8).

IFNy inhibits foam cell transformation of macrophages. ScR-mediated uptake of modified lipoproteins represents a major route for lipid accumulation and foam cell transformation of macrophages. Thus, it was reasonable to believe that IFN $\gamma$-induced reduction of ScR expression may result in an inhibition of the transformation of macrophages into foam cells. To test this possibility, we established a long-term culture system to induce in vitro foam cell development in macrophage cultures. Adherent monocytes differentiated into ma-
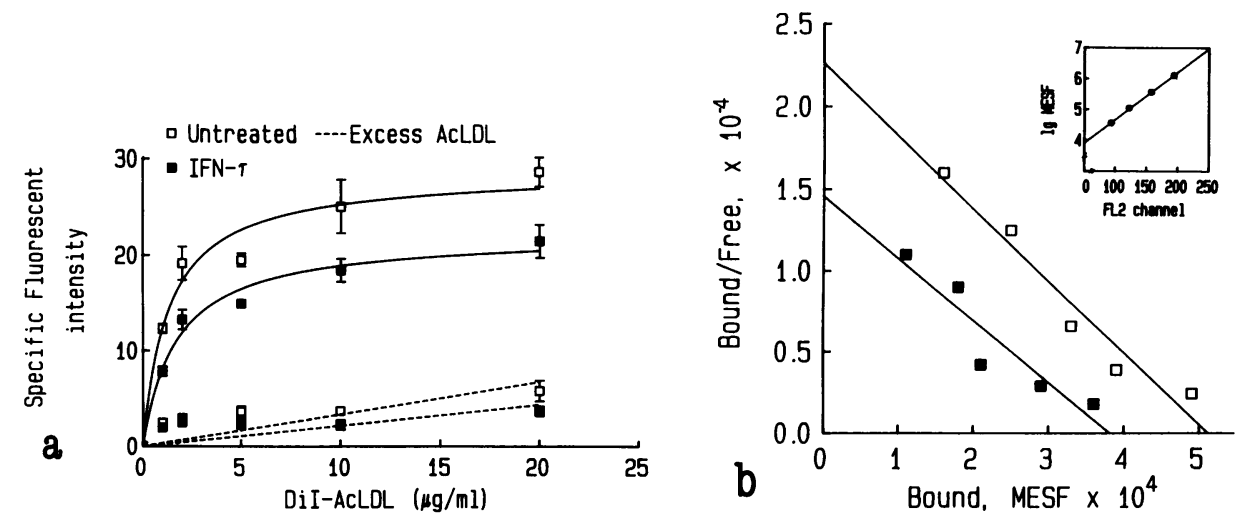

Figure 5. Characterization of rIFN $\gamma$ effect on AcLDL binding to macrophages. Cells were grown in the presence of absence of rIFN $\gamma$ as described in the legend to Fig. 4, incubated with the indicated concentrations of DiI-AcLDL for $30 \mathrm{~min}$ at $4^{\circ} \mathrm{C}$, and analyzed by flow cytometry. Specific fluorescent intensity was calculated as described in the legend to Fig. 2. Values from four different experiments were used to generate curves with the GraphPAD (ISI, Philadelphia, PA) program. Bars represent SEM $(n=4)$. (a) Binding of AcLDL to macrophages. Dotted lines show binding in the presence of $400 \mu \mathrm{g} / \mathrm{ml}$ unlabeled AcLDL, and solid lines represent specific binding as calculated by subtracting binding in the presence of unlabeled AcLDL from total binding in the absence of unlabeled AcLDL. (b) Scatchard plot of data shown in $a$. ( $\square$ ) Specific binding in untreated cultures; ( $\square$ ) specific binding in IFN $\gamma$-treated cultures. (Inset) Calibration curve for the FL2 photomultiplier of the flow cytometer, with fluorescent channels on the $x$-axis and molecules of equivalent soluble fluorochromes (MESF, $\log$ units) on the $y$-axis. 

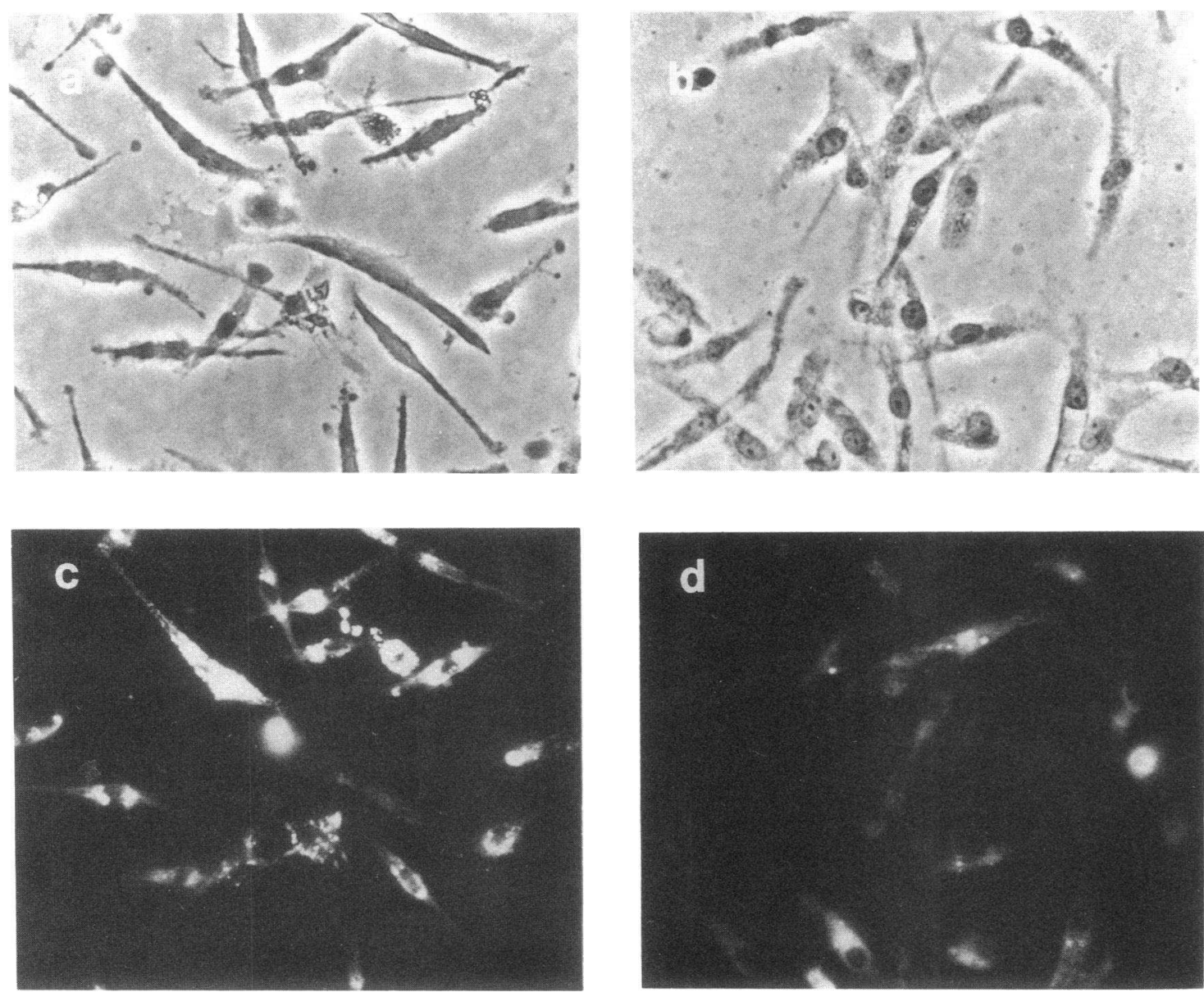

Figure 6. Cellular distribution of DiI in macrophages after uptake of Dil-AcLDL. Monocytes were cultured for 1 wk to permit differentiation into macrophages. They were exposed to rIFN $\gamma(100 \mathrm{U} / \mathrm{ml})$ during the last $3 \mathrm{~d}$, incubated with DiI-AcLDL for $3 \mathrm{~h}$ at $37^{\circ} \mathrm{C}$ and analyzed by fluorescent microscopy. Magnification, $\times 180$ in all micrographs. (a) Phase-contrast micrograph of untreated control culture; (b) phase contrast micrograph of rIFN $\gamma$-treated culture; $(c)$ fluorescent micrograph of untreated culture (same field as in $a$ ) showing the distribution of Dil fluorescence in the perinuclear region of most cells; $(d)$ fluorescent micrograph of rIFN $\gamma$-treated culture (same field as in $b$ ) showing a reduction in Dil fluorescent intensity and the number of DiI-positive cells but not in the distribution of Dil fluorescence in each cell.

ture macrophages during a 2-wk culture period. This differentiation was reflected in dramatic morphologic changes as well as in an upregulation of ScR expression (data not shown). Incubation of these cells with AcLDL $(25 \mu \mathrm{g} / \mathrm{mL}$ for $2 \mathrm{~d})$ but not with native LDL even at higher concentrations, resulted in the occurrence of a number of foam cells filled with large cytoplasmic lipid droplets (Fig. 9 a). Analysis of lipids extracted from such cells indicated that they were dominated by cholesteryl
123
$\mathrm{Kb}$
$4.4-$
$2.4-$
$28 s-$
Figure 7. rIFN $\gamma$ reduces $\mathrm{ScR}$ expression on the mRNA level. Northern analysis of ScR mRNA in rat aortic smooth mus- cle cells (lane 1 ); rIFN $\gamma$ treated (lane 2) and untreated (lane 3) human monocyte-derived macrophages. $15 \mu \mathrm{g}$ of total RNA was separated by formalde- hyde-agarose electrophoresis, blotted to nitrocellulose membranes, and hybrid- ized with an antisense oligonucleotide to type I ScR mRNA. The upper panel shows ScR hybridization and the lower one ethidium bromide staining of the membrane.

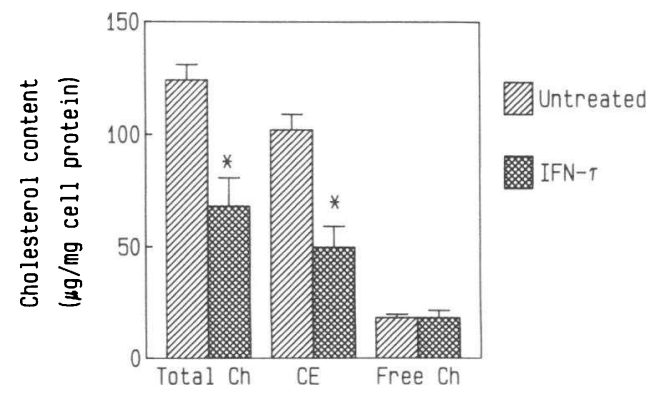

Figure 8. rIFN $\gamma$ reduces cholesterol content in macrophages. Monocyte-derived macrophages were cultured for $7 \mathrm{~d}$ and $\operatorname{rIFN} \gamma(1,000$ $\mathrm{U} / \mathrm{ml}$ ) was added to some of the cultures after three days. AcLDL (50 $\mu \mathrm{g} / \mathrm{ml}$ ) was added $20 \mathrm{~h}$ before the end of the incubation. Cellular lipids and proteins were extracted and cholesterol $(C h)$ fractionated into free and esterified $(C E)$ forms by capillary thin-layer chromatography. Bars show means $\pm \operatorname{SEM}(n=5)$. *Significantly different from untreated control culture $(P<0.05)$. 

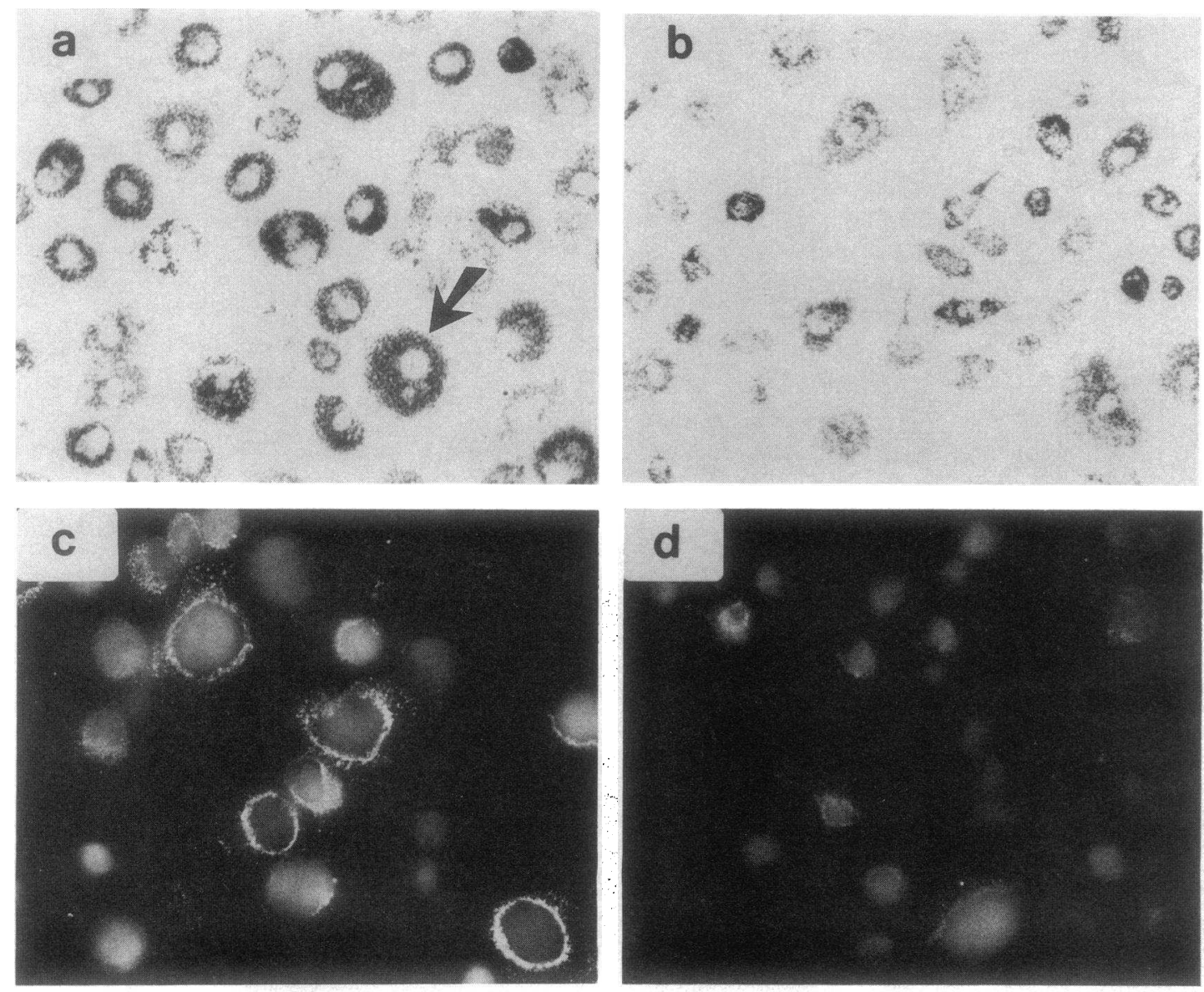

Figure 9. rIFN $\gamma$ inhibits foam cell transformation of monocyte-derived macrophages. Monocyte-derived macrophages were prepared by adherence to plastic and culture under standard conditions for $7 \mathrm{~d}$. They were then grown in the presence or absence of rIFN $\gamma(1,000 \mathrm{U} / \mathrm{ml})$ for another $7 \mathrm{~d}$ and AcLDL at $25 \mu \mathrm{g} / \mathrm{ml}$ was added $2 \mathrm{~d}$ before the end of culture. Cells were stained for lipids with Oil Red O and ScR was visualized in parallel cultures by incubation with DiI-AcLDL $(5 \mu \mathrm{g} / \mathrm{ml})$ at $4^{\circ} \mathrm{C}$ for $30 \mathrm{~min}$ followed by formaldehyde fixation. Magnification, $\times 175$. (a) Oil Red O staining of untreated macrophages shows large amounts of intracellular lipids as cytoplasmic droplets and the transformation of many cells into lipid-laden foam cells (examplified by arrow). (b) IFN $\gamma$-treated macrophages contain fewer and smaller lipid droplets and no foam cells are visible. $(c)$ Visualization of ScR by Dil-AcLDL binding shows a prominent dotted fluorescence in untreated macrophages. $(d)$ Significant reduction in Dil-AcLDL binding in IFN $\gamma$-treated macrophages.

ester. However, treatment of monocyte-macrophages with IFN $\gamma(1,000 \mathrm{U} / \mathrm{ml})$ during the second week of culture led to a remarkable reduction of both the number of foam cells and the number of lipid droplets per cell (Table II; Fig. 9 b).

Table II. AcLDL-induced Foam Cell Formation in Monocytederived Macrophages is Inhibited by IFN $\gamma$

\begin{tabular}{lll}
\hline & \multicolumn{2}{c}{ Percentage of foam cells* } \\
\cline { 2 - 3 } Treatment & -AcLDL & +AcLDL \\
\hline Control & $27.2 \pm 2.7$ & $76.4 \pm 7.1$ \\
IFN $\gamma$ & $17.9 \pm 5.6$ & $25.7 \pm 5.7^{\ddagger}$ \\
\hline
\end{tabular}

Cells were cultured in chamber slides for $14 \mathrm{~d}$. $\operatorname{IFN} \gamma(1,000 \mathrm{U} / \mathrm{ml})$ was added to half of the cultures after $7 \mathrm{~d}$, and AcLDL $(25 \mu \mathrm{g} / \mathrm{ml})$ was added after $12 \mathrm{~d}$. Lipid-laden foam cells were visualized with Oil Red O. Data represent mean \pm SEM of four cultures.

* 400 cells were counted in each culture. Foam cells were identified as macrophages in which the entire cytoplasm was filled with lipid droplets $(1,24)$. Examples are indicated by arrows in Fig. $9 a$. ${ }^{\ddagger}$ Significantly different from AcLDL-treated control cultures $(P<0.01)$
In order to confirm that $\mathrm{ScR}$ expression was reduced in IFN $\gamma$-treated cells in parallel with the reduction in foam cell formation, a Dil-AcLDL binding assay was performed in IFN $\gamma$-treated and untreated macrophages. Fluorescence microscopy revealed an intense, dotted DiI fluorescence on the surface of control macrophages, with a particularly high fluorescence intensity on macrophage foam cells (Fig. 9 c). This fluorescence, which represented surface-bound Dil-AcLDL, was substantially reduced in IFN $\gamma$ treated cells (Fig. $9 d$ ). These observations therefore indicate that ScR expression, cellular cholesteryl ester content, and foam cell formation are affected in the same way by IFN $\gamma$.

\section{Discussion}

The differentiation of monocytes into macrophages is characterized by an increased endocytotic capacity and increased expression of several cell surface proteins including $\operatorname{ScR}$ (17). The differentiation and activation process is regulated by cytokines produced by other cells of the immune system $(17,30,31)$, and conditioned media from activated $\mathrm{T}$ lymphocytes can inhibit ScR expression and uptake of modified lipoproteins in human monocyte-derived macrophages $(32,33)$. The active factor re- 
sponsible for this effect and the mechanism by which it acts, has, however, remained unknown.

Fong et al. (34) recently demonstrated that the IFN $\gamma$ producing helper T cell subset (TH1), but not the IL4-producing TH2 subset, inhibited AcLDL degradation in mouse peritoneal macrophages. They identified IFN $\gamma$ as the active factor and confirmed that rIFN $\gamma$ inhibits AcLDL degradation. However, they could not detect any effect of rIFN $\gamma$ on AcLDL binding and suggested that the inhibitory effect on degradation was mediated by a block in the intracellular transport of internalized AcLDL (34). In contrast, de Whalley and Riches (35) did not detect any effect of IFN $\gamma$ on AcLDL degradation by murine macrophages. They found, however, that poly:I:C, which is an inducer of $\alpha$ - and $\beta$-interferons and an activator of macrophages, inhibited AcLDL degradation (35). Finally, Kraemer et al. (36) found a reduction of $60 \%$ in AcLDL binding by the activated murine macrophages but no effect of activation on the affinity of AcLDL for ScR.

For human macrophages, the situation is equally unclear. The findings of Fogelman et al. (33) established that an (unidentified) product of an IFN $\gamma$-secreting T lymphocyte line could inhibit degradation of malondialdehyde-modified LDL, which is internalized via the ScR. Lopez-Virella et al. (37) also found that AcLDL degradation is reduced in parallel with the degree of activation of macrophages, but surprisingly, IFN $\gamma$ appeared to increase rather than decrease AcLDL degradation in their system.

We have used a different approach to determine the binding and uptake of AcLDL by human monocyte-derived macrophages. Flow cytometry provides a sensitive analysis on a per cell basis and is therefore independent of variations in cellular protein. In addition, cell debris and contaminating cell types can be excluded from the analysis by use of light scatter gates and specific antibody staining.

Our analysis of the binding and uptake of Dil-labeled AcLDL by human macrophages indicates that it is significantly inhibited by IFN $\gamma$ treatment. This extends the observations by Fong et al. (34) in a murine system to the human situation. Furthermore, our experiments with LCM clearly show that IFN $\gamma$ can explain the inhibitory activity towards AcLDL uptake that is produced by activated lymphocytes. This, in turn, strongly suggests that the ScR down-regulating factor detected by Fogelman et al. $(32,33)$ is IFN $\gamma$. The present analysis of human monocyte-derived macrophages shows that AcLDL binding as well as uptake is inhibited by IFN $\gamma$ treatment, indicating that $\mathrm{ScR}$ is down-regulated by IFN $\gamma$. The discrepancy between our results and those of Fong et al. (34) could either be explained by differences in the IFN $\gamma$ response between mice and men, or be due to technical differences, such as the sensitivity of the binding assays. In addition, it is known that $\mathrm{ScR}$ expression varies during monocyte development and differentiation (14). ScR expression is relatively low in circulating monocytes, goes down during the initial adherence but then increases dramatically when the adherent monocyte transforms into a macrophage (14). Studies on cell lines that represent earlier phases in the differentiation pathway and investigations of circulating or immature cells may therefore give results on ScR expression that differ from those obtained with differentiated macrophages.

The cDNA cloning of the ScR (9-11) has increased our understanding of this receptor in several ways. First, a structural model for the receptor could be deduced (9-11). Second, the broad binding specificity could be understood in the light of the collagen-like structure of the putative ligand-binding domain. Third, knowledge of the mRNA sequence for the ScR opens up the possibility to study $\mathrm{ScR}$ regulation on the mRNA level. We have used this latter possibility in the present study and constructed antisense oligonucleotide probes for Northern hybridization analysis of ScR mRNA.

Our hybridization analysis indicates that type I ScR mRNA is present as a $4.4 \mathrm{~kb}$ transcript in human monocyte-derived macrophages. This extends the observations of Kodama et al. (9) on the promonocytic cell line, THP-1, to nontransformed monocyte-derived macrophages. In contrast, ScR type I mRNA could not be detected in rat aortic smooth muscle cells. In view of the high degree of homology for this mRNA among mammals (12), it is likely that the type I ScR is not expressed (or expressed at very low levels) by this cell type.

Treatment with rIFN $\gamma$ dramatically reduced type I ScR mRNA. This indicates that IFN $\gamma$ down-regulates ScR expression on the mRNA level. Taken together, our hybridization and binding data suggest that at least part of the reduced AcLDL uptake and degradation in IFN $\gamma$ treated cells is due to a reduced expression of ScR. The mechanism by which IFN $\gamma$ reduces the steady-state level of ScR mRNA is, however, still unclear, and further studies are needed to clarify whether it takes place on the transcriptional level or more distally in the expression pathway.

The reduced AcLDL uptake in IFN $\gamma$ treated cells was paralleled by a reduction in cellular cholesterol. Incubation of macrophages with AcLDL led to an increase in total cholesterol, which was largely due to an accumulation of cholesteryl esters in intracellular lipid droplets. IFN $\gamma$ treatment significantly reduced cholesteryl ester content and prevented the transformation of the macrophages into foam cells. This indicates that a down-regulation of ScR expression and AcLDL uptake can block the development of foam cells. It will, however, be important to evaluate the relative importance of ScR downregulation vs. changes in the intracellular processing of internalized AcLDL (34) for the rather dramatic inhibition of cholesteryl ester accumulation and foam cell formation caused by IFN $\gamma$ treatment.

Wilson et al. (38) recently reported that in vivo treatment with IFN resulted in suppression of aortic atherosclerosis and arterial cholesterol deposition in cholesterol-fed rabbits. Although the mechanism of the in vivo effect of IFN remains to be determined, these observations together with the recent identification of ScR mRNA and protein in foam cells of human atherosclerotic plaques $(11,13)$ and the present finding that IFN $\gamma$ down-regulates $\mathrm{ScR}$ expression, open up the possibility to prevent cholesterol accumulation in atherosclerotic lesions by mimicking the immunoendocrine modulation of ScR.

Finally, the finding that IFN $\gamma$ down-regulates ScR expression and cholesterol accumulation in macrophages sheds light on the role of T lymphocytes in atherosclerotic lesions. Several years ago, we demonstrated that $\mathrm{T}$ lymphocytes constitute a significant proportion of the cell population in human plaques (3). Many of these T lymphocytes are in an activated state (39) and there is evidence for local IFN $\gamma$ secretion both directly by immunohistochemistry (39) and indirectly by the induction of histocompatibility gene expression in surrounding cells (40). IFN $\gamma$ has previously been shown to inhibit smooth muscle cell proliferation $(19,41,42)$ and $\alpha$-actin expression in smooth muscle cells (42). We now demonstrate that it reduces choles- 
terol accumulation in macrophages. These observations may imply that $\mathrm{T}$ lymphocytes, in addition to any immunologically specific role, may serve as local inhibitors of the atherogenic process.

\section{Acknowledgments}

We thank Monika Hellstrand and Stina Nygren for technical assistance, Lillemor Mattsson for carrying out the cholesterol analyses, Drs. Sven-Olof Olofsson and Göran Bondjers for critical reading of the manuscript, and Dr. David Bowyer for sharing unpublished results.

This work was supported by the Swedish Medical Research Council (project no. 6816 and 9435), the Swedish Heart-Lung Foundation, and Research Funds of Gothenburg University.

\section{References}

1. Schaffner, T., K. Taylor, E. J. Bartucci, J. Fischer-Dzoga, H. Beeson, S Glagov, and R. W. Wissler. 1980. Arterial foam cells with distinctive immunomorphologic and histochemical features of macrophages. Am. J. Pathol. 100:5780.

2. Gerrity, R. G. 1981. The role of the monocyte in atherogenesis. I. Transition of blood-borne monocytes into foam cells in fatty lesions. Am. J. Pathol. 103:181-190.

3. Jonasson, L., J. Holm, O. Skalli, G. Bondjers, and G. K. Hansson. 1986. Regional accumulations of $\mathrm{T}$ cells, macrophages, and smooth muscle cells in the human atherosclerotic plaque. Arteriosclerosis. 6:131-138.

4. Gown, A. M., T. Tsukada, and R. Ross. 1986. II. Immunocytochemica analysis of the cellular composition of human atherosclerotic lesions. Am. J. Pathol. 125:191-207.

5. Brown, M. S., and J. L. Goldstein. 1983. Lipoprotein metabolism in the macrophage: Implications for cholesterol deposition in atherosclerosis. Annu. Rev. Biochem. 52:223-261.

6. Fogelman, A. M., B. J. van Lenten, C. Warden, M. E. Haberland, and P. A. Edwards. 1988. Macrophage lipoprotein receptors. J. Cell. Sci. Suppl. 9:135-149.

7. Steinberg, D., S. Parthasarathy, T. E. Carew, J. C. Khoo, and J. L. Witztum. 1989. Beyond cholesterol: modifications of low-density lipoprotein that increase its atherogenicity. N. Engl. J. Med. 320:915-924.

8. Goldstein, J. C., Y. K. Ho, S. K. Basu, and M. S. Brown. 1979. Binding site on macrophages that mediates uptake and degradation of acetylated low density lipoprotein producing massive cholesterol deposition. Proc. Natl. Acad. Sci. USA. 76:168-178.

9. Kodama, T., M. Freeman, L. Rohrer, J. Zabrechy, P. Matsudaira, and M. Krieger. 1990. Type I macrophage scavenger receptor contains $\alpha$ helical and collagen-like coiled coils. Nature (Lond.). 343:531-535.

10. Rohrer, L., M. Freeman, T. Kodama, M. Penman, and M. Krieger. 1990. Coiled-coil fibrous domains mediate ligand binding by macrophage scavenger receptor type II. Nature (Lond.). 343:570-572.

11. Matsukomoto, A., M. Naito, H. Itakura, S. Ikemoto, H. Asaoka, K. Hayakawa, H. Kanamori, H. Aburatani, F. Takaku, H. Suzuki, et al. 1990. Human macrophage scavenger receptors: primary structure, expression, and localization in atherosclerotic lesions. Proc. Natl. Acad. Sci. USA. 87:9133-9137.

12. Freeman, M., J. Ashkenas, D. J. G. Rees, M. Kingsley, N. G. Copeland, N. A. Jenkins, and M. Krieger. 1990. An ancient, highly conserved family of cysteine-rich protein domains revealed by cloning type I and type II murine macrophage scavenger receptors. Proc. Natl. Acad. Sci. USA. 87:8810-8814.

13. Ylä-Herttuala, S., M. E. Rosenfeld, S. Parthasarathy, E. Sigal, T. Särkioja, J. L. Witztum, and D. Steinberg. 1991. Gene expression in macrophage-rich human atherosclerotic lesions: 15-lipoxygenase and acetyl low density lipoprotein receptor messenger RNA colocalize with oxidation specific lipid-proteins adducts. J. Clin. Invest. 87:1146-1152.

14. Fogelman, A. M., M. E. Haberland, J. Seager, M. Hokom, and P. A. Edwards. 1981. Factors regulating the activities of the low density lipoprotein receptor and the scavenger receptor on human monocyte-macrophages. J. Lipid Res. 22:1131-1141.

15. Via, D. P., L. Pons, D. K. Dennison, A. E. Fanslow, and B. Bernini. 1989 Induction of acetyl-LDL receptor activity by phorbol ester in human monocyte cell line THP-1. J. Lipid Res. 30:1515-1524.

16. Hara, H., H. Tanashita, S. Yokoyama, S. Tajima, and A. Yamamoto 1987. Induction of acetylated low density lipoprotein receptor and suppression of low density lipoprotein receptor on the cells of human monocyte leukemia cell line (THP-1 cell). Biochem. Biophys. Res. Commun. 146:802-808.

17. Adams, D. O., and T. A. Hamilton. 1984. The cell biology of macrophage activation. Annu. Rev. Immunol. 2:283-318.
18. Dimitriu-Bona, A., G. R. Burmester, S. J. Waters, and R. J. Winchester. 1983. Human mononuclear phagocyte differentiation antigens. I. Patterns of antigenic expression on the surface of human monocytes and macrophages defined by monoclonal antibodies. J. Immunol. 130:145-152.

19. Hansson, G. K., L. Jonasson, J. Holm, M. M. Clowes, and A. W. Clowes. 1988. $\gamma$-Interferon regulates vascular smooth muscle proliferation and Ia expression in vivo and in vitro. Circ. Res. 63:712-719.

20. Jonasson, L., G. K. Hansson, G. Bondjers, L. Noe, and J. Etienne. 1990. Interferon- $\gamma$ inhibits lipoprotein lipase in human monocyte-derived macrophages. Biochim. Biophys. Acta. 1053:43-48.

21. Voyta, J. C., D. P. Via, C. E. Butterfield, and B. R. Zetter. 1984. Identification and isolation of endothelial cells based on their increased uptake of acetyllow density lipoprotein. J. Cell Biol. 99:2034-2040.

22. Jaakkola, O., O.-P. Kallioniemi, and T. Niikari. 1988. Lipoprotein uptake in primary cell cultures of rabbit atherosclerotic lesions. Atherosclerosis. 69:257268.

23. Vogt, R. F., G. D. Cross, L. O. Henderson, and D. L. Philips. 1982. A model system evaluating fluorescein-labeled microbeads as internal standards to calibrate fluorescence intensity on flow cytometers. Cytometry. 10:294-302.

24. Newman, H. A. I., T. M. Murad, and J. C. Geer. 1971. Foam cells of rabbit atheromatous lesion. Identification and cholesterol uptake in isolated cells. $L a b$. Invest. 25:586-595.

25. Hara, A., and N. S. Radin. 1978. Lipid extraction of tissues with a low-toxicity solvent. Anal. Chem. 90:420-426.

26. Lowry, O. H., N. J. Rosebrough, A. L. Farr, and R. J. Randall. 1951. Protein measurement with the Folin phenol reagent. J. Biol. Chem. 258:46064611.

27. Boström, K., J. Borén, M. Wettesten, A. Sjöberg, G. Bondjers, O. Wiklund, P. Carlsson, and S-O. Olofsson. 1988. Studies on the assembly of apo B-100 containing lipoproteins in HepG2 cells. J. Biol. Chem. 263:4434-4442.

28. Auffray, C., and R. Rougeon. 1980. Purification of mouse immunoglobulin heavy-chain messenger RNAs from total myeloma tumor RNA. Eur. J. Biochem. 107:303-314.

29. van Lenten, B. J., A. M. Fogelman, J. Seager, E. Ribi, M. E. Haberland, and P. A. Edwards. 1985. Bacterial endotoxin selectively prevents the expression of scavenger-receptor activity on human monocyte-macrophages. J. Immunol. 134:3718-3721.

30. Mokoena, T., and S. Gordin. 1985. Human macrophage activation: Modulation of mannosyl, fucosyl receptor activity in vitro by lymphokines, $\gamma$ and $\alpha$ interferons, and dexamethasone. J. Clin. Invest. 75:620-631.

31. Adams, D. O. 1989. Molecular interactions in macrophage activation. Immunol. Today. 10:33-35

32. Fogelman, A. M., J. Seager, M. E. Haberland, M. Hokom, R. Tanaka, and P. A. Edwards. 1982. Lymphocyte-conditioned medium protects human monocyte-macrophages from cholesterol ester accumulation. Proc. Natl. Acad. Sci. USA. 79:922-926.

33. Fogelman, A. M., J. Seager, E. Groopman, J. A. Berliner, M. E. Haberland, P. A. Edwards, and D. W. Golde. 1983. Lymphokines secreted by an established lymphocyte line modulate receptor-mediated endocytosis in macrophages derived from human monocytes. J. Immunol. 131:2368-2373.

34. Fong, L. G., A. T. Fong, and A. D. Cooper. 1990. Inhibitions of mouse macrophage degradation of acetyl-low density lipoproteins by interferon- $\gamma$. $J$. Biol. Chem. 265:11751-11760.

35. de Whalley, C. V., and D. W. Riches. 1991. Influences of the cytocidal macrophage phenotype on the degradation of acetylated low density lipoproteins: dual regulation of scavenger receptor activity and of intracellular degradation of endocytosed ligand. Exp. Cell. Res. 192:460-469.

36. Kraemer, F. B., K. Tavangar, R. K. Gandjei, K. Kirlew, and S. R. Behr. 1990. Effects of activation on lipid and lipoprotein metabolism in murine macrophages. Arteriosclerosis. 10:8-16.

37. Lopez-Virella, M. F., R. L. Klein, and H. C. Stevenson. 1987. Low density lipoprotein metabolism in human macrophages stimulated with microbial-related products. Arteriosclerosis. 7:176-184.

38. Wilson, A. C., R. G. Shaub, R. C. Goldstein, and P. T. Kuo. 1990. Suppression of aortic atherosclerosis in cholesterol-fed rabbits by purified rabbit interferon. Arteriosclerosis. 10:208-214.

39. Hansson, G. K., J. Holm, and L. Jonasson. 1989. Detection of activated T lymphocytes in the human atherosclerotic plaque. Am. J. Pathol. 135:169-175.

40. Jonasson, L., J. Holm, O. Skalli, G. Gabbiani, and G. K. Hansson. 1985. Expression of class II transplantation antigen on vascular smooth muscle cells in human atherosclerosis. J. Clin. Invest. 76:125-131.

41. Warner, S. J. C., G. B. Friedman, and P. Libby. 1989. Immune interferon inhibits proliferation and induces 2'-5'-oligoadenylate synthetase gene expression in human vascular smooth muscle cells. J. Clin. Invest. 83:1174-1182.

42. Hansson, G. K., M. Hellstrand, L. Rymo, L. Rubbia, and G. Gabbiani 1989. Interferon- $\gamma$ inhibits both proliferation and expression of differentiationspecific $\alpha$-smooth muscle actin in arterial smooth muscle cells. J. Exp. Med. 170:1595-1608. 